Original

\title{
Tumor Necrosis Factor- $\alpha$ Expression and Kupffer Cell Activation in Hepatotoxicity Caused by Microcystin-LR in Mice
}

\author{
Toshinori Yoshida ${ }^{1}$, Makio Takeda $^{2}$, Tomoaki Tsutsumi ${ }^{4}$, Satoshi Nagata ${ }^{4}$, \\ Fuyuko Yoshida ${ }^{4}$, Keizo Maita ${ }^{3}$, Takanori Harada ${ }^{1}$, and Yoshio Ueno ${ }^{4}$ \\ ${ }^{1}$ Laboratory of Pathology, Toxicology Division II \\ ${ }^{2}$ Laboratory of Biochemical Toxicology, Toxicology Division II \\ ${ }^{3}$ Division of Study Planning and Consultation, Institute of Environmental Toxicology, Uchimoriya-machi 4321, \\ Mitsukaido-shi, Ibaraki 303-0043, Japan \\ ${ }^{4}$ Research Institute for Biosciences and Department of Toxicology and Microbial Chemistry, Faculty of Pharmaceutical \\ Sciences, Science University of Tokyo, Funakawara-machi 12, Ichigaya, Shinjyuku-ku, Tokyo 162-0826, Japan
}

\begin{abstract}
The aim of this study was to examine tumor necrosis factor- $\alpha$ (TNF- $\alpha$ ) expression and Kupffer cell activation in hepatotoxicity caused by microcystin-LR (MCLR). Mice received a single intraperitoneal injection of $60.0 \mu \mathrm{g} / \mathrm{kg}$ MCLR and were killed at several time points within 24 hours. MCLR caused hemorrhage within 7 hours, followed by hepatocellular necrosis and apoptosis. A real-time quantitative reverse-transcription polymerase chain reaction demonstrated that the level of TNF- $\alpha$ mRNA was 2.3 -fold higher than in the controls at 17 hours. The number of TNF$\alpha$-immunopositive nonparenchymal cells was 2.6 - and 7.7 -fold greater than that in the controls at 7 and 17 hours, respectively, and they frequently infiltrated into necrotic areas, probably in association with neutrophil recruitment. Some apoptotic hepatocytes were immunopositive for cleaved caspase-3. To inactivate Kupffer cells, mice were pretreated with a single intravenous injection of gadolinium chloride $\left(\mathrm{GdCl}_{3}, 2 \mathrm{mg} / \mathrm{mouse}\right)$. That brought about the apoptosis of sinusoidal cells, which indicated Kupffer cell depletion. $\mathrm{GdCl}_{3}$ pretreatment attenuated MCLR-induced hepatocellular apoptosis by $68 \%$, and likely decreased hepatocellular necrosis. These results suggest that Kupffer cell activation, represented by enhanced TNF- $\alpha$ expression, is involved in the progression of MCLR-induced hepatotoxicity in mice. (J Toxicol Pathol 2001; 14: 259-265)
\end{abstract}

Key words: Kupffer cell, tumor necrosis factor- $\alpha$, necrosis, apoptosis, gadolinium chloride, microcystin-LR.

\section{Introduction}

Microcystins (MCs) are cyclic heptapeptides produced by some species of freshwater cyanobacteria such as Microcystis aeruginosa. In human and a number of animal species, exposure to microcystin (MC) resulted in liver failure and death, raising significant public health concerns $^{1,2}$. Indeed, enzyme-linked immunosorbent assays have revealed widespread MC contamination of various recreation and drinking water sources ${ }^{3,4}$ and dietary supplements ${ }^{5}$. In a disastrous 1996 incident in Caruaru, Brazil, more than 100 hemodialysis patients developed liver failure with microcystin-LR (MCLR), one of the MC groups

Received: 28 June 2001, Accepted: 20 August 2001

Mailing address: Toshinori Yoshida, Laboratory of Pathology,

Toxicology Division II, Institute of Environmental Toxicology,

Uchimoriya-machi 4321, Mitsukaido-shi, Ibaraki 303-0043, Japan

TEL: 81-297-27-4521 FAX: 81-297-27-4518

E-mail: yoshida@iet.or.jp most toxic, confirmed in the patient's serum and liver, and about half of them died ${ }^{6,7}$. MCs inhibit the activity of protein phosphatases 1 and 2A (PP1/2A), which may play a pivotal role in hepatotoxicity, and they are potent hepatic tumor promoters $^{1,2}$.

A single administration of MCLR to mice causes intrahepatic hemorrhage and death within a few hours. Livers of mice that survive 24 hours show hepatocellular necrosis and apoptosis ${ }^{8-10}$. In our previous study, liver injuries occur in association with intralobular distribution of MCLR that is demonstrated by immunohistochemistry with anti-MC monoclonal antibody ${ }^{11}$. MCLR predisposition as a mechanism of liver injuries is, however, insufficient to account for the development of hepatocellular necrosis and apoptosis $^{12}$. In the liver, enhanced production of tumor necrosis factor- $\alpha$ (TNF- $\alpha$ ), which is released mainly from Kupffer cells, plays a critical role in the initiation of injuries and cell proliferation ${ }^{13-16}$. Although evidence regarding the role of TNF- $\alpha$ in the pathogenesis of MCLR toxicity is not fully understood, only one animal study is available 
regarding the potential pathological effect. Intraperitoneal injection of a crude extract of Microcystis aeruginosa K-139 strain causes up-regulation of serum TNF- $\alpha$ in mice in 30 minutes; pretreatment with TNF- $\alpha$ antiserum prevents some of the liver damage and protects against death ${ }^{17}$. Cultured mouse peritoneal macrophages produce TNF- $\alpha$ in the presence of an extract from the toxic K-139 strain and 7desmethyl-MCLR purified from K-139 strain in a dosedependent manner, while the macrophages hardly produce TNF- $\alpha$ in the presence of an extract of nontoxic K-17 strain. Little attention, however, has been paid to the expression and distribution of TNF- $\alpha$ in the liver.

The objective of the present study was to examine the expression of TNF- $\alpha$ in the liver from mice 24 hours after MCLR administration by a real-time quantitative reversetranscription polymerase chain reaction (RT-PCR) and immunohistochemistry. Because TNF- $\alpha$-mediated apoptosis depends on the action of effector caspases such as caspase- $3^{14}$, we also analyzed cleaved (active form) caspase3. Moreover, we determined if pretreatment with gadolinium chloride $\left(\mathrm{GdCl}_{3}\right)$ would, as a consequence of Kupffer cell inactivation ${ }^{16}$, modify hepatic injury after MCLR challenge.

\section{Materials and Methods}

\section{Animals and treatments}

Fifteen female Balb/c mice were purchased from CLEA Japan Inc. (Shizuoka) and 20 female ICR (Crj:CD-1) mice were purchased from Charles River Japan, Inc. (Kanagawa). They were kept in a barrier-sustained animal room controlled at suitable temperature $\left(24 \pm 2{ }^{\circ} \mathrm{C}\right)$, humidity $(55 \pm$ $15 \%$ ), ventilation (all-fresh-air system), and illumination (12-hour-light-dark cycle). They were housed in groups of 5 per cage and provided with pelleted diet (Oriental MF, Oriental Yeast Co., Tokyo) and tap water ad libitum. All animals were handled in accordance with the Guidelines for Animal Experimentation issued by the Japanese Association for Laboratory Animal Science ${ }^{18}$. The purity of MCLR was more than $95 \%$ by high performance liquid chromatography (HPLC). The concentration of MCLR solution given to mice was confirmed by HPLC.

For the observation of the time-related changes induced by MCLR, 15 nine-week-old Balb/c mice were injected intraperitoneally with $60.0 \mu \mathrm{g} / \mathrm{kg}$ MCLR dissolved in saline as previously described ${ }^{12}$. The animals were killed by exsanguination at 7 and 17 hours $(n=5$ at each time point) under anesthesia. Control mice $(n=5)$ received saline alone and were killed 30 minutes later, just before the treated mice received MCLR (0 hour).

For the examination of the effect of $\mathrm{GdCl}_{3}$ on MCLR hepatotoxicity, 20 nine-week-old ICR mice were divided into 2 groups of 10; one group received a single intravenous injection of $2 \mathrm{mg} \mathrm{GdCl}_{3}$ dissolved in saline as a pretreatment $^{19}$; the other group received saline alone. At 24 hours after the pretreatment, each group was divided into 2 subgroups; half of the mice in each were given intraperitoneally $60 \mu \mathrm{g} / \mathrm{kg}$ MCLR dissolved in saline, and the other half were given saline alone. The mice were killed under anesthesia at 24 hours after MCLR or saline injection.

For the examination of liver effects, samples from the midportion of the left and median lobes were fixed in $10 \%$ neutral buffered formalin and embedded in paraffin. For the time-course study, portions of the lobes were embedded in Tissu Mount (Chiba Medical, Saitama) and frozen with dry ice-ethanol for immunohistochemistry. The rest of the tissue was immediately frozen and stored at $-80^{\circ} \mathrm{C}$ until used for RNA isolation.

\section{Histopathology, TUNEL, and immunohistochemistry}

Paraffin-embedded sections were stained with hematoxylin and eosin for routine histology and for applied terminal deoxynucleotidyl transferase-mediated dUTP nick end labeling (TUNEL) with an Apoptag in situ apoptosis detection kit (Intergen Company, Purchase, NY) ${ }^{20}$. To observe neutrophils, we performed a modified AS-D chloroacetate procedure ${ }^{21}$. For cleaved caspase-3 immunohistochemistry, paraffin-embedded sections were deparaffinized, washed in phosphate buffered saline at $\mathrm{pH}$ 7.2 , and pretreated with microwaves in $0.1 \mathrm{M}$ citrate buffer at $\mathrm{pH} 6.0$ for 10 minutes. They were incubated in $4 \%$ Block Ace solution (Dainippon Pharmaceutical Ltd., Osaka) for 20 minutes at room temperature, and then at $4^{\circ} \mathrm{C}$ overnight in anti-cleaved caspase-3 $(17 \mathrm{kDa})$ rabbit polyclonal antibody (Cell Signaling Technology, Beverly, MA) diluted 1:50. For TNF- $\alpha$ immunohistochemistry, fresh-frozen sections were fixed in acetone for 10 minutes at room temperature and washed in $0.1 \mathrm{M}$ Tris buffer at $\mathrm{pH} 7.4$. To reduce nonspecific staining, they were incubated at room temperature in $4 \%$ Block Ace solution for 20 minutes and a biotin-avidin blocking kit (Vector Laboratories, Burlingame, CA) for 15 minutes. The sections were incubated in anti-TNF- $\alpha$ rabbit polyclonal antibody (ENDOGEN, Woburn, MA), diluted $1: 400$, at $4^{\circ} \mathrm{C}$ overnight. Bound antibody was detected by an avidin-biotin-complex method with biotinylated rabbit $\mathrm{IgG}$, streptoavidin (SA)-horseradish peroxidase conjugate (Vector Laboratories), and substrate, 3,3'-diaminobenzidine for cleaved caspase-3 or with biotinylated rabbit IgG, SAalkaline phosphatase conjugate (Vector Laboratories), and substrate, New fucsin (Dako Corp., Carpinteria, CA) containing levamisole (DAKO Corp.) for TNF- $\alpha$. Finally, all sections were counterstained with hematoxylin. No specific immunoreactivity was observed when the primary antibodies were omitted. Red designated positive reactions for AS-D chloroacetate and anti-TNF- $\alpha$ antibody, and brown designated positive reactions for TUNEL and anticleaved caspase-3 antibody.

\section{Morphometry}

For the time-course study, we used 0-, 7- and 17-hour liver samples and counted the number of TNF- $\alpha$ immunopositive non-parenchymal cells in 50 microscope fields $\left(6.1 \mathrm{~mm}^{2}\right)$ per animal at $\times 400$ magnification by superimposing a stereological grid $(7 \times 7 \mathrm{~mm})$; results were 
expressed as cells $/ \mathrm{mm}^{2}$. For the $\mathrm{GdCl}_{3}$ pretreatment study, to determine the effect of MCLR, the number of TUNELpositive hepatocyte nuclei per at least 1000 hepatocyte nuclei (TUNEL index of hepatocyte, \%) was microscopically quantified in the centrilobular and midlobular regions. To determine the effect of $\mathrm{GdCl}_{3}$, the number of TUNEL-positive nuclei in sinusoidal cells per at least 1000 sinusoidal cell nuclei (TUNEL index of sinusoidal cell, \%) was also counted at random within a lobule. Necrotic areas were measured by manual tracing with the aid of a LUZEX III image analysis system (Nireco Co., Tokyo), and the fraction (\%) occupied by necrotic areas per liver section was determined.

\section{Real-time quantitative $R T-P C R$}

We isolated total RNA from 0-, 7- and 17-hour liver samples according to ISOGEN (Nippon gene, Toyama) instructions, reverse-transcribed $100 \mathrm{ng}$ into cDNA with TaqMan Reverse Transcription Reagent (PE Applied BioSystems, Foster City, CA), and stored the product at $-20^{\circ} \mathrm{C}$ until use. We carried out real-time quantitative PCR (TaqMan PCR) using an ABI PRISM ${ }^{\text {TM }} 7700$ Sequence Detection System and a TaqMan Universal PCR Master Mix (PE Applied BioSystems). We used each $2 \mu \mathrm{l}$ of the first strand of cDNA for quantitation of TNF- $\alpha$ and GPADH mRNAs with Pre-Developed TaqMan Assay Reagents (Murine TNF alpha) and TaqMan Rodent GAPDH Control Reagents (PE Applied BioSystems). The conditions for the TaqMan PCR were one cycle at $95^{\circ} \mathrm{C}$ for 10 minutes followed by 50 cycles at $95^{\circ} \mathrm{C}$ for 15 seconds and $60^{\circ} \mathrm{C}$ for 1 minute. We applied the relative kinetic method using a standard curve $\mathrm{e}^{22}$, as shown in Fig. 1. To obtain the standard curve, 17 hours after treating mice we serially diluted 25:5:1 mixed samples from 5 of them corresponding to $5.0,1.0$, and $0.2 \mu \mathrm{l}$ of cDNAs, respectively. We used the plots to determine the threshold cycle $\left(\mathrm{C}_{\mathrm{T}}\right)$, i.e., the PCR cycle at which an increase in reporter fluorescence $(\Delta \mathrm{Rn})$ above the line of the optimal value (optimal $\mathrm{Rn}$ ) was first detected. The standard curve plotted $\mathrm{C}_{\mathrm{T}}$ versus relative gene expression (25:5:1). We also obtained a standard curve for GAPDH. Relative gene expression was calculated for unknown samples by first quantifying GADPH mRNA and then TNF- $\alpha$ mRNA, both by standard curves. The expression levels of TNF- $\alpha$ mRNA were shown as the TNF- $\alpha$ :GAPDH mRNA ratio.

\section{Statistical analysis}

Data are represented as means and standard deviation. The data on TNF- $\alpha$ :GAPDH mRNA ratio and the number of TNF- $\alpha$-immunopositive cell were analyzed by KruskalWallis one-way analysis of variance (ANOVA) followed by Steel's nonparametric multiple comparison test between the control group at 0 hour and the treatment group at each time point. The TUNEL index of hepatocyte or sinusoidal cell and necrotic area fraction were analyzed by two-way ANOVA followed by Tukey's multiple comparison test. A $\mathrm{p}$ value below 0.05 was judged statistically significant.
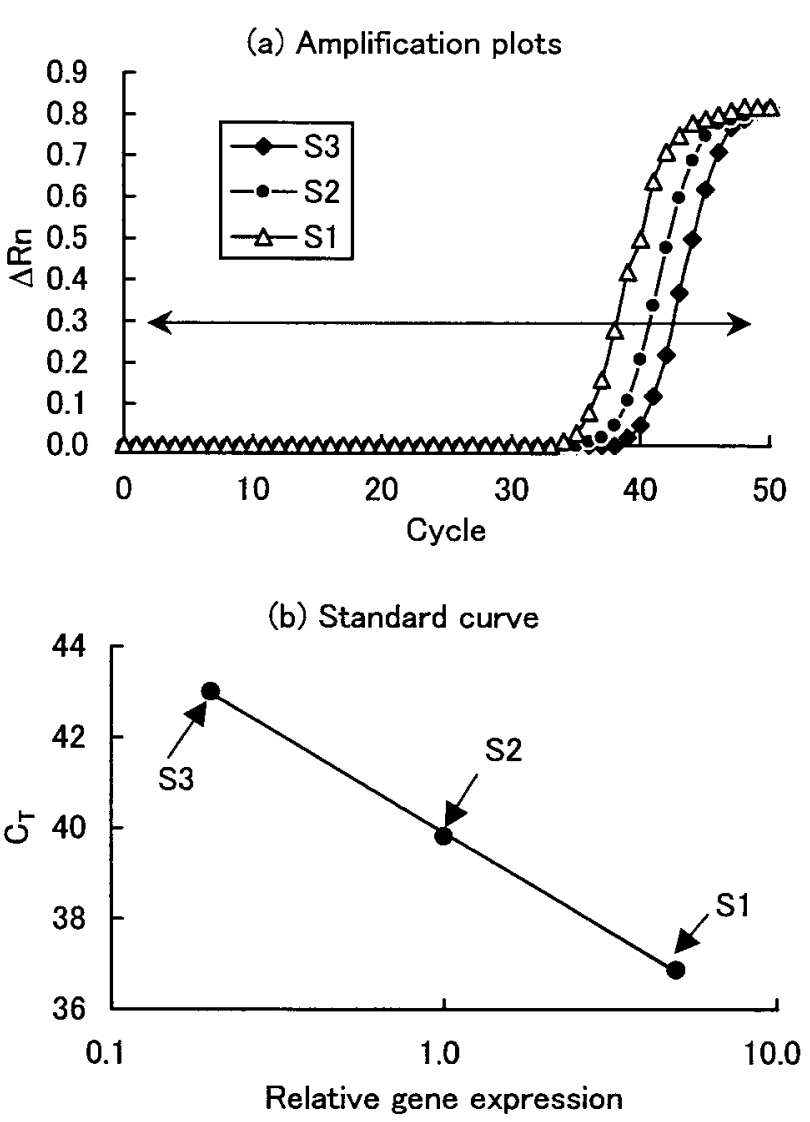

Fig. 1. TNF- $\alpha$ standard curve by a real-time quantitative RT-PCR. (a) Amplification plots for reactions at three points (S1, 5.0 $\mu \mathrm{l}$; S2, $1.0 \mu \mathrm{l}$; S3, $0.2 \mu \mathrm{l}$ ) of standard cDNAs. The horizontal line shows the optimal $\Delta \mathrm{Rn}$. (b) A plot of the threshold cycle $\left(C_{T}\right)$ versus relative gene expression $(25: 5: 1)$ (common logarithmic scale).

\section{Results}

\section{Time-related hepatic changes}

In the liver, MCLR caused centrilobular hemorrhage within 7 hours of dosing and then hepatocellular necrosis and apoptosis in the centrilobular and midlobular regions at 17 hours, as previously described ${ }^{12}$. Neutrophils positive for AS-D chloroacetate markedly infiltrated into necrotic foci. TUNEL-positive hepatocellular apoptosis was present in the centrilobular and midlobular regions, often associated with hepatocellular necrosis. Cleaved caspase-3 immunoreactivity was found only in apoptotic hepatocytes, which showed chromatin condensation, nuclear fragmentation, and cytoplasmic condensation in the centrilobular and midlobular regions (Fig. 2a) and at the margin of necrotic foci (Fig. 2b).

\section{Expression of TNF- $\alpha$}

The hepatic TNF- $\alpha$ :GAPDH mRNA ratio was $50 \%$ higher than the control at 7 hours but this was not significantly different, while the ratio was of significantly 2.3-fold higher value at 17 hours (Fig. 3a). The number $/ \mathrm{mm}^{2}$ 


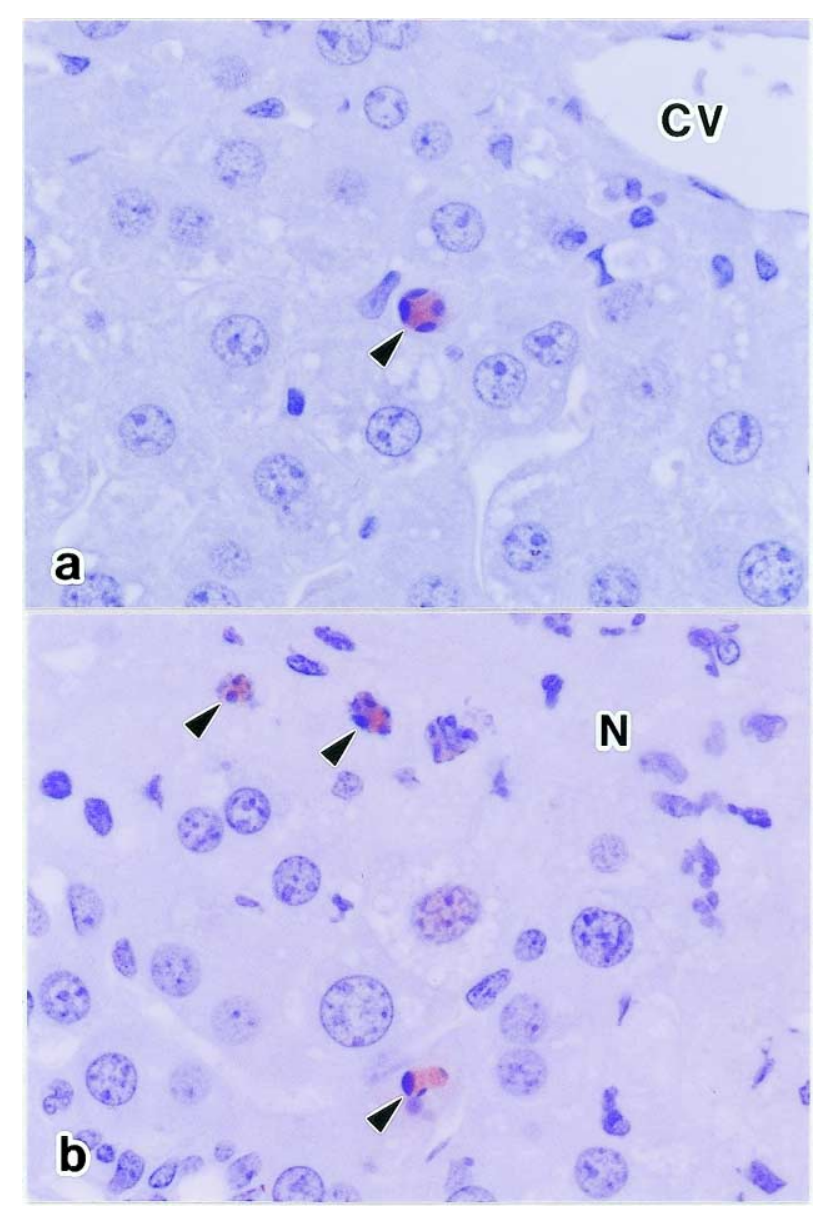

Fig. 2. Immunohistochemistry with anti-cleaved caspase-3 antibody in the liver from a treated mouse at 17 hours after treatment. The positive reaction is evident in typical apoptotic hepatocytes (arrowheads) in the centrilobular region (a) and at the margin of a necrotic focus (b). CV: Central vein. N: Necrotic focus. $\times 590$

of TNF- $\alpha$-immunopositive non-parenchymal cells was 2.6 times the control value at 7 hours and 7.7 times the control value at 17 hours (Fig. 3b). These cells were scattered throughout the lobules at each time point (Fig. 3c) and also frequently observed within necrotic areas.

\section{Effects of $\mathrm{GdCl}_{3}$ on MCLR liver injury}

At 48 hours after $\mathrm{GdCl}_{3}$ treatment, mineralized polygonal sinusoidal cells, which seemed consistent with Kupffer cells, were frequently observed. $\mathrm{GdCl}_{3}$ caused a significant 2.8-fold increase in TUNEL index of sinusoidal cells that was related to Kupffer cell disruption (Figs. 4a, b). A similar magnitude of increase in TUNEL index, 1.6-fold, was also observed in mice after cotreatment of $\mathrm{GdCl}_{3}$ and MCLR. Blockade of Kupffer cells by $\mathrm{GdCl}_{3}$ pretreatment significantly attenuated MCLR-induced hepatocellular apoptosis (Fig. 5a) by 68\%, and likely, but not significantly, decreased hepatocellular necrosis (Fig. 5b). (a)

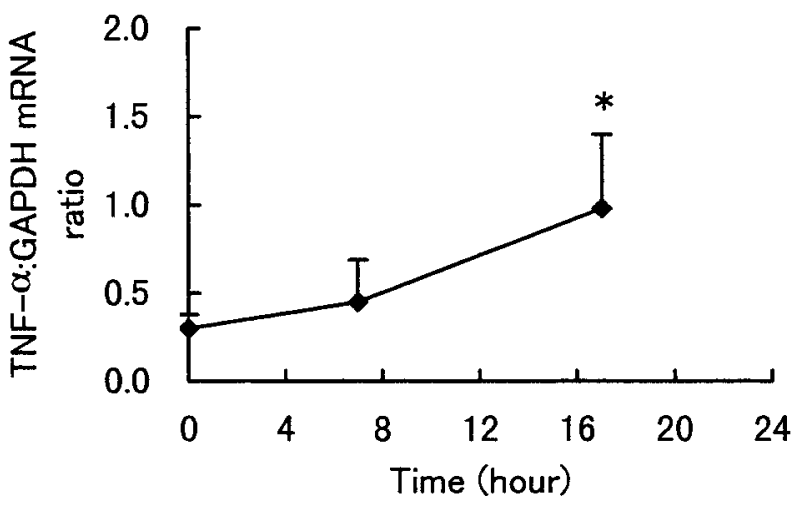

(b)
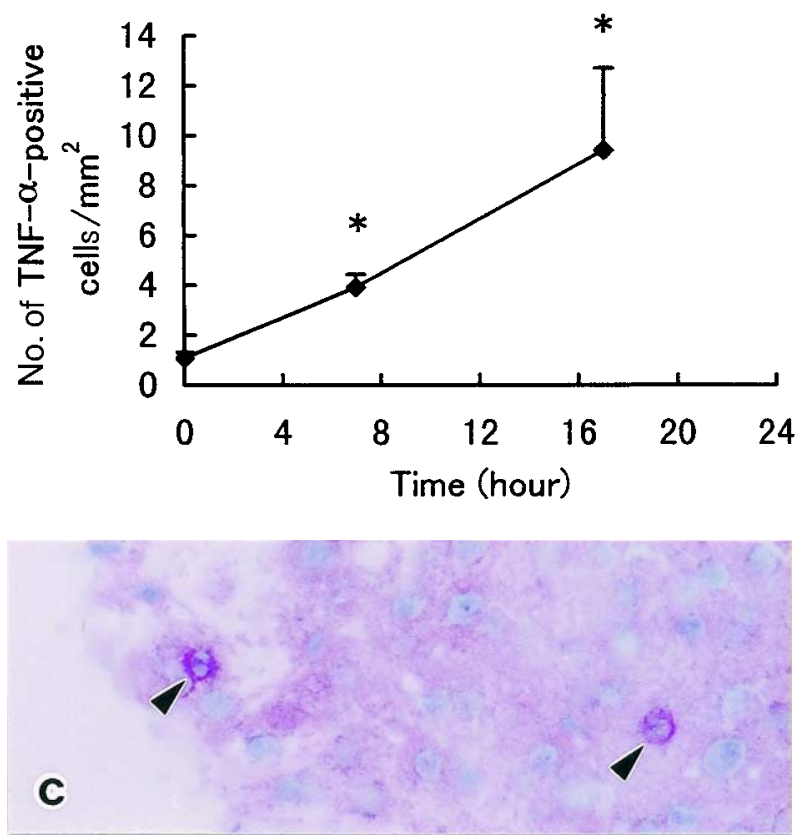

Fig. 3. Expression of TNF- $\alpha$ by real-time quantitative RT-PCR (a) and immunohistochemistry $(b, c)$ in the liver from treated mice. (a) The expression levels of TNF- $\alpha$ mRNA are shown as TNF- $\alpha$ :GAPDH mRNA ratio. (b) No. of TNF- $\alpha$-positive cells $/ \mathrm{mm}^{2} . *=\mathrm{p}<0.05$ versus control ( 0 hour). (c) TNF- $\alpha$ positive non-parenchymal cells (arrowheads) in the liver from a treated mouse at 7 hours after treatment. $\times 370$

\section{Discussion}

This study illustrated a role for TNF- $\alpha$ in the liver toxicity induced when MCLR was given to mice. Quantitative assessment of TNF- $\alpha$ mRNA demonstrated that this cytokine was up-regulated and associated with the development of post-hemorrhagic changes, i.e., necrosis and apoptosis. A number of previous studies have shown that MCLR causes hemorrhagic sinusoidal breakdown in rats and mice ${ }^{8-10}$ that is presumed to be caused by inhibition of PP1/ $2 \mathrm{~A}$ and subsequent hyperphosphorylation of cytokeratins 


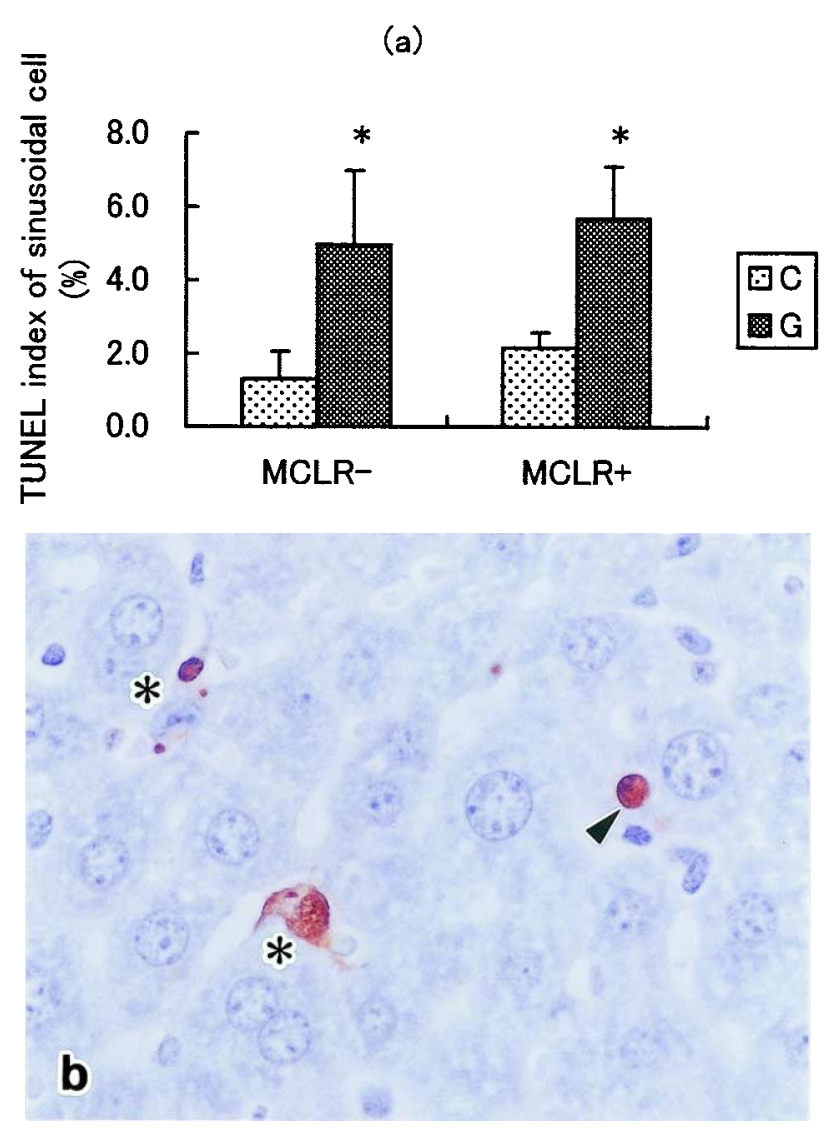

Fig. 4. Effect of $\mathrm{GdCl}_{3}$ in sinusoidal cell in the liver. (a) TUNEL index of sinusoidal cell. $\mathrm{C}=$ Control. $\mathrm{G}=\mathrm{GdCl}_{3} .{ }^{*}=\mathrm{p}<0.05$ versus corresponding group without $\mathrm{GdCl}_{3}$ pretreatment. (b) TUNEL in the liver of mice cotreated with $\mathrm{GdCl}_{3} / \mathrm{MCLR}$. TUNEL-positive cells are noted in the hepatocyte (arrowhead) and sinusoidal cells (asterisks). $\times 590$.

and desmoplakins ${ }^{1,2,23}$. Little, however, is known about how hepatocellular necrosis and apoptosis take place subsequent to the sinusoidal changes ${ }^{9,12}$. TNF- $\alpha$ mRNA up-regulation may correlate with the increase in population of TNF- $\alpha$ immunopositive non-parenchymal cells, which seemed to correspond to the infiltration of macrophages and the activation of Kupffer cells that was recently reported by an electron microscopic study ${ }^{24}$. TNF- $\alpha$ has been shown to directly or indirectly (via neutrophil mediation) induce damage of endothelial cells and neighboring parenchymal cells, inducing a response that may be linked to the production of reactive oxygen species (ROS) ${ }^{15,16}$. TNF- $\alpha$ mediated tissue injury in this study was partly in accord with the previous study that suggested that the inflammatory reaction plays a major role in the generation of oxidative stress in rats that had undergone prolonged exposure to this $\operatorname{toxin}^{25}$.

The binding of TNF- $\alpha$ to death receptors or the targeting of mitochondria by ROS is recognized as a sign of activated executioner caspases, including caspase- $3^{14}$. MCLR causes rapid apoptosis within 2 minutes $(16 \mathrm{mM} / \mathrm{L})$

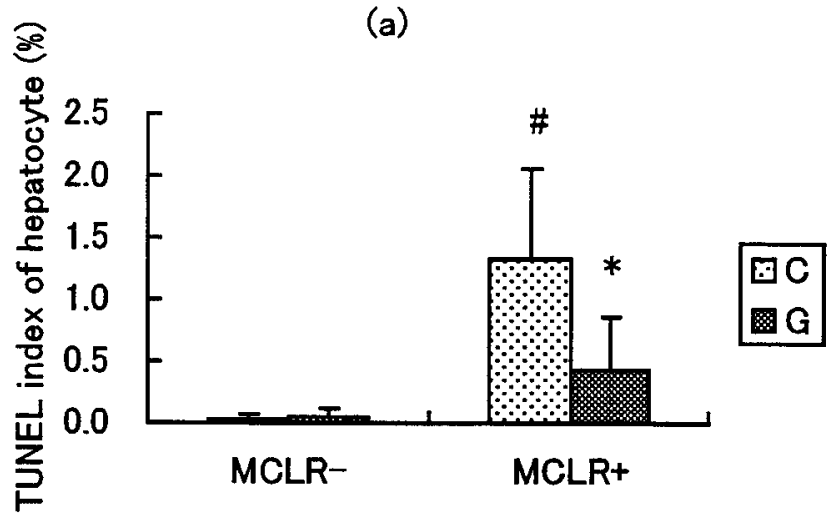

(b)

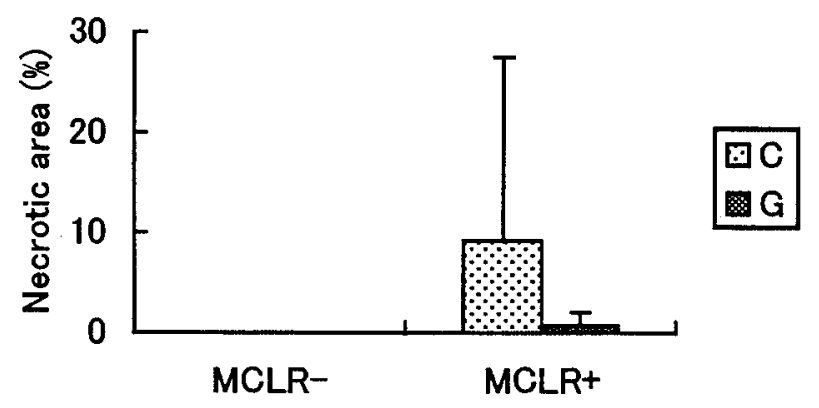

Fig. 5. Effects of $\mathrm{GdCl}_{3}$ on TUNEL index of hepatocyte (a) and necrotic area fraction (b) in the liver. $\mathrm{C}=$ Control. $\mathrm{G}=\mathrm{GdCl}_{3}$. $*=\mathrm{p}<0.05$ versus corresponding group without $\mathrm{GdCl}_{3}$ pretreatment. $\#=\mathrm{p}<0.05$ versus control group without $\mathrm{GdCl}_{3} /$ MCLR cotreatment.

or 30 minutes $(1 \mathrm{mM} / \mathrm{L})$ in vitro when mediated by ROS generation and PP1/2A inhibition followed by caspase-3 activation $^{26,27}$. It has been suggested that phosphatase inhibitors, including MCLR, might have evolved an ability to provide a short-cut to the apoptotic pathway ${ }^{26}$. The present study demonstrated that caspase-3-dependent apoptosis could occur in combination with up-regulation of TNF- $\alpha$ in vivo. Immunohistochemical labeling of cleaved caspase- 3 can identify cells in which activation of the rapid apoptosis pathway has taken place ${ }^{28}$. In contrast to the in vitro situation, where apoptosis is a rather early event in MCLR toxicity, apoptosis in vivo seems to be a later event, occurring after hemorrhagic changes ${ }^{12,29}$. Because it is most likely that late apoptosis follows from MCLR-PP1/2A adduct formation rather than $\mathrm{PP} 1 / 2 \mathrm{~A}$ inhibition ${ }^{29}$, it is probable that apoptosis in vivo is associated with TNF- $\alpha$ in addition to MCLR-PP1/2A adduct formation.

It is generally accepted that Kupffer cell is a main source of TNF- $\alpha$. A single intravenous injection with $\mathrm{GdCl}_{3}$ leads to (a) prominent depletion of KCR mRNA specific to Kupffer cells, (b) immunoreactivity for ED1/ED2, which are markers for Kupffer cells and macrophages, and (c) phagocytic activity in the liver for 12 hours to about 3 
days ${ }^{30,31}$. The present study demonstrated that $\mathrm{GdCl}_{3}$ increased the TUNEL index of sinusoidal cells, which might be consistent with an increase in mineralized Kupffer cells, possibly due to the deposition of insoluble Gd hydroxide colloid $^{32}$. The colloid inhibits $\mathrm{Ca}^{2+}$ channels, which leads to Kupffer cell disruption ${ }^{31}$. Blockade of Kupffer cells by $\mathrm{GdCl}_{3}$ pretreatment ameliorated MCLR-induced hepatocellular damage. The results suggested that Kupffer cells might be partially responsible for the development of hepatocellular necrosis and apoptosis following MCLR challenge.

In conclusion, the present results suggested that hepatocellular damage in MCLR-exposed mice might occur in association with expression of TNF- $\alpha$. Kupffer cell depletion resulted in alleviation of the hepatocellular damage, indicating a critical role for Kupffer cells in the progression of MCLR hepatotoxicity.

Acknowledgment:We thank Misses Y Chiba, K Sakamoto, M Kumagai, T Tomiyama, T Kazami, and Y Tateyama and Mr H Fujisawa, Institute of Environmental Toxicology (IET), for tissue preparation. We also thank Drs N Nakashima, T Kitazawa, A Enomoto, M Kuwahara, and Y Takeuchi, IET, for their helpful suggestions.

\section{References}

1. Chorus I, and Bartram J. editors. Toxic Cyanobacteria in Water. A Guide to Their Public Health Consequences, Monitoring and Management. London: E \& FN Spon, 1999.

2. Hitzfeld BC, Höger SJ, and Dietrich DR. Cyanobacterial toxins: Removal during water treatment, and human risk assessment. Environ Health Perspect 2000; 108 (suppl 1): $113-122$

3. Ueno $Y$, Nagata $S$, Tsutsumi T, Hasegawa A, Watanabe FM, Park H-D, Chen G-C, Chen G, and Yu S-Z. Detection of microcystins, a blue-green algal hepatotoxin, in drinking water sampled in Haiman and Fusui, endemic areas of primary liver cancer in China, by highly sensitive immunoassay. Carcinogenesis 1996; 17: 1317-1321.

4. Ueno Y, Nagata S, Tsutsumi T, Hasegawa A, Yoshida F, Suttajit M, Mebs D, Pütsch M, and Vasconcelos V. Survey of microcystins in environmental water by a highly sensitive immunoassay based on monoclonal antibody. Nat Toxins 1996; 4: 271-276.

5. Gilroy DJ, Kauffman KW, Hall RA, Huang X, and Chu FS. Assessing potential health risks from microcystin toxins in blue-green algae dietary supplements. Environ Health Perspect 2000; 108: 435-439.

6. Jochimsen EM, Carmichael WW, An JS, Cardo DM, Cookson ST, Holmes CEM, de C Antunes MB, de Melo Filho DA, Lyra TM, Barreto VST, Azevedo SMFO, and Jarvis WR. Liver failure and death after exposure to microcystins at a hemodialysis center in Brazil. N Eng J Med 1998; 338: 873-878. [Erratum published in N Eng J Med 1998; 339: 139]

7. Pouria S, de Andrade A, Barbosa J, Cavalcanti RL, Barreto VTS, Ward CJ, Preiser W, Poon GK, Neild GH, and Codd GA. Fatal microcystin intoxication in haemodialysis unit in Caruaru, Brazil. Lancet 1998; 352: 21-26.
8. Hooser SB, Beasley VR, Lovell RA, Carmichael WW, and Haschek WM. Toxicity of microcystin LR, a cyclic heptapeptide hepatotoxin from Microcystis aeruginosa, to rats and mice. Vet Pathol 1989; 26: 246-252.

9. Lovell RA, Schaeffer DJ, Hooser SB, Haschek WM, Dahlem AM, Carmichael WW, and Beasley VR. Toxicity of intraperitoneal doses of microcystin-LR in two strains of male mice. J Environ Pathol Toxicol Oncol 1989; 9: 221238.

10. Yoshida T, Makita Y, Nagata S, Tsutsumi T, Yoshida F, Sekijima M, Tamura S-I, and Ueno Y. Acute oral toxicity of microcystin-LR, a cyanobacterial hepatotoxin, in mice. Nat Toxins 1997; 5: 91-95.

11. Yoshida T, Makita Y, Tsutsumi T, Nagata S, Tashiro F, Yoshida F, Sekijima M, Tamura S-I, Harada T, Maita K, and Ueno Y. Immunohistochemical localization of microcystinLR in the liver of mice: A study on the pathogenesis of microcystin-LR-induced hepatotoxicity. Toxicol Pathol 1998; 26: 411-418.

12. Yoshida T, Tsutsumi T, Nagata S, Yoshida F, Maita K, Harada T, and Ueno Y. Quantitative analysis of intralobular distribution of microcystin-LR in the mouse liver. J Toxicol Pathol, 2001; 14: 205-212.

13. Fausto N. Liver regeneration. J Hepatol 2000; 32 (suppl 1): 19-31.

14. Kaplowitz N. Mechanisms of liver cell injury. J Hepatol 2000; 32 (suppl 1): 39-47.

15. Lentsch AB, and Ward PA. Regulation of inflammatory vascular damage. J Pathol 2000; 190: 343-348.

16. Luster MI, Simeonova PP, Gallucci R, and Matheson J. Tumor necrosis factor $\alpha$ and toxicology. Crit Rev Toxicol 1999; 29: 491-511.

17. Nakano Y, Shirai M, Mori N, and Nakano M. Neutralization of microcystin shock in mice by tumor necrosis factor alpha antiserum. Appl Environ Microbiol 1991; 57: 327-330.

18. Japanese Association for Laboratory Animal Science. Guidelines for animal experimentation. Exp Anim 1987; 36: 285-288.

19. Shiratori $Y$, Hongo S, Hikiba $Y$, Ohmura K, Nagura T, Okano K, Kamii K, Tanaka T, Komatsu Y, Ochiai T, Tsubouchi H, and Omata M. Role of macrophages in regeneration of liver. Digest Dis Sci 1996; 41: 1939-1946.

20. Gavrieli Y, Sherman Y, and Ben-Sasson SA. Identification of programmed cell death in situ via specific labeling of nuclear DNA fragmentation. J Cell Biol 1992; 119: 493501.

21. Jaeschke H, Farhood A, Fisher MA, and Smith CW. Sequestration of neutrophils in the hepatic vasculature during endotoxemia is independent of $\beta_{2}$ integrins and intercellular adhesion molecule-1. Shock 1996; 5: 351-356.

22. Winer J, Jung CKS, Shackel I, and Williams PM. Development and validation of real-time quantitative reverse transcriptase-polymerase chain reaction for monitoring gene expression in cardiac myocytes in vitro. Anal Biochem 1999; 270: 41-49.

23. Toivola DM, Goldman RD, Garrod DR, and Eriksson JE. Protein phosphatases maintain the organization and structural interactions of hepatic keratin intermediate filaments. J Cell Sci 1997; 110: 23-33.

24. Yoshida T, Nakamura Y, Tsutsumi T, Nagata S, Yoshida F, Maita K, Harada T, and Ueno Y. Transmission electron and immunoelectron microscopic studies on microcystin-LR- 
induced hepatic injuries in mice. J Toxicol Pathol 2001; 14: 157-161.

25. Guzman RE, and Solter PF. Hepatic oxidative stress following prolonged sublethal microcystin LR exposure. Toxicol Pathol 1999; 27: 582-588.

26. Ding W-X, Shen H-M, and Ong C-N. Critical role of reactive oxygen species and mitochondrial permeability transition in microcystin-induced rapid apoptosis in rat hepatocytes. Hepatology 2000; 32: 547-555.

27. Fladmark KE, Brustugun OT, Hovland R, Bøe R, Gjertsen BT, Zhivotovsky B, and Døskeland SO. Ultrarapid caspase3 dependent apoptosis induction by serine/threonine phosphatase inhibitors. Cell Death Differ 1999; 6: 10991108 .

28. Stadelmann C, Deckwerth TL, Srinivasan A, Bancher C, Brück W, Jellinger K, and Lassmann H. Activation of caspase- 3 in single neurons and autophagic granules of granulovascular degeneration in Alzheimer's disease. Evidence for apoptotic cell death. Am J Pathol 1999; 155:
$1459-1466$.

29. Fischer WJ, Hitzfeld BC, Tencalla F, Eriksson JE, Mikhailov A, and Dietrich DR. Microcystin-LR toxicodynamics, induced pathology, and immunohistochemical localization in livers of blue-green algae exposed rainbow trout (Oncorhynchus mykiss). Toxicol Sci 2000; 54: 365-373.

30. Hardonk MJ, Dijkhuis FWJ, Hulstaert CE, and Koudstaal J. Heterogeneity of rat liver and spleen macrophages in gadolinium chloride-induced elimination and repopulation. J Leukoc Biol 1992; 52: 296-302.

31. Rai RM, Yang SQ, McClain C, Karp CL, Klein AS, and Diehl AM. Kupffer cell depletion by gadolinium chloride enhances liver regeneration after partial hepatectomy in rats. Am J Physiol 1996; 270: G909-G918.

32. Spencer AJ, Wilson SA, Batchelor J, Reid A, Rees J, and Harpur E. Gadolinium chloride toxicity in the rat. Toxicol Pathol 1997; 25: 245-255. 